\title{
Directive Expressions of The Main Characters in Green Book Movie
}

\author{
Sakut Anshori ${ }^{1}$, Fahmi Gunawan ${ }^{2}$, Yopi Thahara ${ }^{3}$ \\ Institut Agama Islam Negeri Curup, Jln. DR.AK.Gani no.1 Curup ${ }^{1}$ \\ Institut Agama Islam Negeri Kendari, Jln. Sultan Qaimuddin No 10 Kendari, \\ Indonesia $^{2}$ \\ Universitas Abdurachman Saleh Situbondo, Jl. Pb. Sudirman No.07, Kabupaten \\ Situbondo, Jawa Timur, Indonesia ${ }^{3}$ \\ \{sakutanshori@gmail.com¹, fgunawanp@gmail.com,2yopi.thahara@gmail.com ${ }^{3}$ \}
}

\begin{abstract}
This paper presents the study of speech act specifically directive expressions in the Green Book movie. This research used qualitative paradigm with embedded case study. The results of the study showed that there were 52 directive expressions founded in the orientation, complication, and resolution. In the orientation, there were ordering $(11,6 \%)$, demanding $(3,8 \%)$, suggesting $(1,9 \%)$, and asking $(1,9 \%)$. In the conflict phase, directive expressions were in the form of ordering $(19,2 \%)$, demanding $(7,7 \%)$, commanding $(7,7 \%)$, suggesting $(3,8 \%)$, asking $(1,9 \%)$. In the resolution phase, directive expressions were found in the form of suggesting $(13,6 \%)$, ordering $(11,6 \%)$, commanding $(5,8 \%)$, demanding $(3,8 \%)$, asking $(1,9 \%)$, and inviting $(1,9 \%)$. Ordering expressions dominated the orientation and conflict phase because the relationship between two characters were interpersonal relations in the form of power relation and peerage. Meanwhile, resolution phase are dominated with suggesting expressions because the relationship between two characters were close and the power relation diminished.
\end{abstract}

Key words: Directive speech act, movie, green book, oscar

\section{INTRODUCTION}

Directive is one of speech act found commonly in everyday communication. Directive expression is used by speakers to convey their intention of communication which is understandable by the hearer [1]. It can be both interrogative and declarative expressions. Searle explained that the directive speech acts are an illocutionary act that aims to produce an effect in the form of the action taken by the addressees [2]. Yule also argued that the directive speech act is a speech act which is used by speaker to get someone else to do something [3]. Directive speech acts are studied in this research because of some reasons. First, directive speech act is a kind of speech act that is often used by speakers in daily communication. By using directive, the speakers attempt to make the world fit the word via the hearer. Second, directive shows a strong relationship between speaker and hearer. Third, directive speech acts are used to get great attention from listeners in communication [4]. 
In this research, directive speech acts are taken from Green Book movie. The movie talked about friendship between a white man and a black man in the 1960's. The black man was jazz musician. He was looking for a driver to accompany him in the tour. He occupied Tony Lip, a white man who had "brutal" personality, as a driver. In their tour, they were equiped with The Negro Motorist Green Book, a guide book for African - American about safe place for the black men. The setting of the movie was the situation in the Deep South, North America in the 1960. Frank "Tony Lip" Vellalonga (Viggo Mortensen) was a security in the night club in New York City. He lost his job because the club where he had been working was closed because it was under renovation. One day, he was called by his friend to meet Dr. Shirley in the Concert Hall for job interview. Dr. Shirley needed a driver to accompany him in his concert tour for eight weeks in Deep South. Since that meeting, Tony was occupied by Dr. Shirley to be his driver. Their journey didn't go well at the beginning. Tony with his "brutal" personality was in contrast to Don Shirley's personality that looked calm and educated. However, as time goes by, they suppressed their egos and accepted their differences. In the tour, Don Shirley always got unpleasant treatment from the white people. Tony always protected Don Shirley from the danger in their tour journey. Besides, Don Shirley taught Tony about how to behave in good manner and how to communicate with his wife. Because of its' unique, this film won the best comedy film in the Golden Globe Awards and some other awards. This film was nominated the five categories in the Oscar, including the best film, the best actor, the best supporting actor, the best film editing, and the best documentary feature $[5]$.

Green Book film had not been researched by other researchers, because the film just won the Oscar in 2019. This film depicted unique story about power relation and racism. Some previous researchers have investigated directive speech acts. The directive speech acts were studied in the futuristic world film in which society was divided into five factions; Amity, Abnegation, Candor, Erudite, and Dauntless [4], non-fiction film [6], and the translation of directive speech act in novel [7],[8],[9]. Therefore, this research aims at examining directive speech acts uttered by the main characters in Green Book Movie.

\section{METHODOLOGY}

Qualitative approach with embedded case study was used in this research. In this research, the data from Green Book movie were in the form utterances of the main characters. The utterances were in the form of words, phrases, clauses, or sentences. The data source of this research is the script of Green Book movie. To collect the data, the researchers used the video of the film to determine directive speech acts. Then, the researchers make note of the directive speech acts in the movie. The data collected are classified by using Yule's speech act theory. To analyze the data, the researchers used ethnography theory proposed by Spradley that was modified by Santosa [18]. The analysis consisted of domain analysis, taxonomy analysis, componential analysis, and finding cultural values.

\section{FINDINGS AND DISCUSSION}

Austin stated that when people speak or state something, they also do something or make an act, it is called speech acts [19]. Speech acts are the types of acts performed by a speaker in uttering a sentence [13] and has been developed by a British philosopher John Searle. He developed speech act theory from a basic belief that language is used to perform actions. 
Then, John Searle classifies illocutionary act into five [2], directives, commisives, assertives, expressives, declaratives. In term of directive speech act, Allan classifies four classes of directives [20], they are: 1 . Requestives. The speaker requests the hearer/addressee to do an act (something). Requestive performatives include: ask, beg, implore, insist, invite, petition, plead, pray, solicit, summon, tell, urge. 2. Questions. It means that the speaker questions the hearer/addressee as to proposition. Questioning performatives include: ask, inquire, query, question, quiz. 3. Requirements. It means that the speaker requires the hearer/addressee to do an act. Requiring performatives include: big, charge, command, demand, dictate, instruct, order, prescribe, require. 4. Prohibitives. The speaker prohibits the hearer/addressee from doing an act. Prohibitive performatives include: enjoin, forbid, prohibit, proscribe, restrict. 5. Permissive. It means that the speaker permits the hearer/addressee to do an act. Permissive performatives include: agree to, allow, authorize, bless, consent to, dismiss, excuse, exempt, forgive, grant leave or permission, license, pardon, permit, release, sanction. 6. Advisories. It means that the speaker advises the hearer/addressee to do an act. The speaker intends the utterance to be taken as sufficient reason for the hearer to do an act. Advisory performatives include: admonish, advise, caution, counsel, propose, recommend, suggest, urge, warn [22-23].

The results showed that directive speech acts based on the theory were 52 data. Generally, directive speech acts were in the form of ordering 22 utterances (42,3\%), suggesting 10 utterances $(19,2 \%)$, demanding 8 utterances $(15,4 \%)$, commanding 7 utterances $(13,5 \%)$, asking 3 utterances $(5,8 \%)$, begging 1 untterance $(1,9 \%)$, and inviting 1 utterance $(1,9 \%)$. However, the directive speech acts were spread out of all structures of Green Book movie; orientation, complication, and resolution. There were dominant directive speech act in every phase of the film. The description of each phase are in the following section.

\subsection{Orientation}

Orientation in the film is also called introducing general description about the film in order to make the viewer understand the film storyline [21]. It consists of introduction of the characters in the film. In this film, general description introduced the two main characters Tony Lip and Dr. Shirley. Frank "Tony Lip" Vellalonga was night club security in New York City, who had to lose his job because the club he worked for was under renovation. One day, he met with Don Shirley (Mahershala Ali), a famous jazz pianist. Shirley needed a driver to accompany with in his concert tour for eight weeks at Deep South. That was the start of Tony works for him. In the orientation, directive speech acts of main characters consisted of ordering $6(11,6 \%)$, demanding $2(3,8 \%)$, suggesting $1(1,9 \%)$. The directive speech acts were in the form of ordering, demanding, suggesting, and asking. The data are as follow:

Data 1

Context: Toni Lip told goods keeper girl in the Bar to give Loscudo's hat. Tony gave her money and the girl gave the hat to him.

Tabel 1. Ordering in Orientation

\begin{tabular}{ccc}
\hline Datum & Time & \multicolumn{1}{c}{ Conversation } \\
\hline 1 & $2: 52$ & T: Hey, give me Loscudo's hat. \\
& & G: But he said to guard it. \\
& T: I know. I heard. \\
\hline
\end{tabular}


Ordering in the Thesaurus dictionary is an authoritative indication to be obeyed; a comment or direction [12]. Hence, ordering speech act is utterance that consists of ordering to the hearer to do something. Data (1) shows that the main character Tony ordered the girl to give Loscudo's hat to him. The linguistic evidences were the use of word "give me". The clause give me is addressed to girls which means ordering the girls to give Loscudo's hat to him.

Data 2

Context: Tony was interviewed by Dr. Shirley.

Tabel 2. Suggesting in Orientation

\begin{tabular}{ccl}
\hline Datum & Time & \multicolumn{1}{c}{ Conversation } \\
\hline 2 & $16: 40$ & S: Do you foresee any issues \\
& & working for a black man? \\
& T: no... 'fact just yesterday me and \\
& the wife had a couple colored guys \\
& over the house. For drinks. \\
& S: Oh, I see. You're married. \\
& S: I'm not sure if this is the \\
& proper job for a married man.
\end{tabular}

Data (2) showed suggestion speech act or the act of suggesting. This datum is found when Dr. Shirley asked Tony to be his driver. Dr. Shirley suggested that the job was not appropriate with married man.

Data 3-4

Context: Tony was about to start the tour wtih Dr. Shirley. He would leave his family for about eight weeks. He wanted to say good bye to his family and gave suggestions to his sons.

Tabel 3. Asking and Demanding in Orientation

\begin{tabular}{ccc}
\hline Datum & Time & \multicolumn{1}{c}{ Conversation } \\
3 & $24: 58$ & T: will you be good boys? \\
4 & $25: 02$ & T: You listen to your mother. \\
& & T: give me a kiss. \\
\hline
\end{tabular}

Data (3-4) tell about directive speech acts in the form of asking and demanding. Asking was found in the phrase will you be, on the other hand demanding was found in the clause give me a kiss. The phrase will you be is used to ask his son to be a good boys and the phrase give me a kiss is demanding expression. Tony demanded to his sons to give him a kiss before the tour.

\subsection{Complication}

Complication is the moment when the problems are faced by the main characters in story or film [13]. The scenario writer have to make conflicts in order to make the film interesting. The existences of conflict in the story will make the film exist. However, film cannot attract viewers every single scene of the conflict. The conflict in Green Book film emerged after both main characters started the concert tour. In this phase, directive speech acts of the main 
characters are in the form of ordering, demanding, commanding, suggesting, asking and begging. The total of directive speech acts were 22 utterances. There were 10 ordering speech acts. The context of the utterances were in the several places (4 utterances) and several events (6 utterances). Ordering was the dominant speech act in the complication phase. It could be foreseen because the main character, Dr. Shirley, as a boss ordered his worker to do something. The percentage of ordering speech acts was $19,2 \%$. Demanding was $7,7 \%$ with one place and three events. Asking reached 1,9\% with only one utterance. Suggesting reached $3,8 \%$ ( 2 utterances) and the context refered to the event. The utterance happened in one place. Commanding was 7,7\% with one places and 3 events. Begging and inviting consisted of one utterance $(1,9 \%)$. Speech act in the complication phase can be seen in the following examples.

Data 5

Context: Tony and Dr. Shirley was in the car heading to the first concert place.

Tabel 4. Ordering Speech Acts in Complication

\begin{tabular}{llll}
\hline 5 & Time & & \multicolumn{1}{c}{ Conversation } \\
\hline & $30: 02$ & S: & Could you please put the cigarette out? \\
& T: & Why? \\
& S: & Because I can't breathe back here. \\
\hline
\end{tabular}

Data 6

Context: on the road when they were going to the concert, Tony throw the tea glass from Kentucky friedchicken and Dr. Shirley commanded Tony to take it back.

Tabel 5. Commanding Speech Acts in Complication

\begin{tabular}{ccc}
\hline Datum & Time & \multicolumn{1}{c}{ Conversation } \\
\hline 6 & $54: 11$ & S: Pick it up, Tony! \\
\hline
\end{tabular}

Data (5-6) are the sample of directive speech act in the complication. Data (5) is ordering speech act while data (6) is included in the commanding speech act. The linguistic evidence phrase could you in the data (5) shows ordering speech act. In this case, Tony is ordered to turn cigarette out by Dr. Shirley because he cannot breath because of the smoke. Data (6) is included in commanding because Shirley commanded Tony to take the glass that had just thrown on the road. The linguistic evidence is pick it up and followed by exclamation mark, Tony!. Besides, the tone of Shirley's voice was getting high.

\subsection{Resolution}

Resolution is the story in which the main character get an idea to solve the problem in the complication [14], [15]. In the resolution, there were 20 directive utterances. The directive speech acts in resolution phase in the Green Book movie are in the form of ordering, demanding, asking, suggesting, commanding and inviting. Ordering speech acts were 6 or $11,6 \%$ and found in the three places and three different events. There were $2(3,8 \%)$ utterances of demanding and found in the 2 different events. Asking speech act was $1(1,9 \%)$ and found in 1 context of place. Suggesting speech act were $7(13,6 \%)$ utterances and found in the 2 different context of place and 5 different context of event. Commanding speech act were 3 utterances or reached $5,8 \%$ and found in the 3 different contexts of place. Inviting speech act 
in the film was only 1 data or $1,9 \%$. In the resolution, suggesting speech acts were the dominant because the utterances were used to solve the problem in the complication.

Data 7

Context: Tony took a gem stone from the store but he did not pay the stone.

Tabel 6. Suggesting Speech Act in Resolution

\begin{tabular}{ccl}
\hline Datum & Time & \multicolumn{1}{c}{ Conversation } \\
\hline 7 & $45: 55$ & T: I told you that Kraut was a sneak. \\
& Rats me out for something I didn't even \\
& do. \\
& S: Pay for the stone, Tony, you'll feel \\
& better. \\
& T: I feel fine, and I'm not paying for no \\
& regular rock I found in the dirt. \\
\hline
\end{tabular}

Data (7) showed that Shirley suggested Tony to put the gem stone back to the store. For Shirley, it was a crime and shameful. It can be infered from his statement "before we pull out, Tony, we need to talk. I just heard something that disturbed me a great." Hence, he suggested Tony to pay for the stone. Tony followed the suggestion to put the stone back but surreptitiously he put the stone in his pocket.

Directive speech acts in the Green Book film consisted of ordering, demanding, asking, suggesting, commanding, begging, and inviting. In componential analysis, there are two items that can be discussed. First, ordering is the dominant speech act in the orientation, complication, and resolution. There were 22 utterances that consist ordering, in which 6 in the orientation, 10 in the complication, and 6 in the resolution. Then, it can be assumed because this film tells about the friendship betwaan the boss (black man) with his driver (white man). Second, suggesting speech act is the dominant utterances in the resolution because in this phase conflicts are resolved. One of the way to overcome the conflict is to give suggestions. In this research, the researchers found 10 suggestion utterances.

\section{CONCLUSION}

Power relations, the level of distance and public domain are three things that are very influential in interpersonal communication, especially between the rulers and those who are controlled. The further power relation is, the more formal and polite speech. The closer the power relations are, the more informal and impolite the speech conveyed. Formality and nonformality, politeness and impolite of the speech are also influenced by the level of distance. The more formal and polite a speech is, the less familiar the communicants are. On the contrary, the more familiar the communicant is, the more informal and impolite speech. However, the Green Book films show different things. Shirley's main character as an educated boss conveyed speeches that tended to be calm and polite, while Toni, the driver, delivered harsh speeches even though his power relations were far and the level of distance was also far. In this film, directive speech acts are found in 52 utterances which were classified into three phases, namely the orientation, complication and resolution. In the orientation, the directive speech act was ordered speech acts (11.6\%), demanding (3.8\%), suggesting (1.9\%), and asking $(1.9 \%)$. In the complication, directive speech acts were ordered (19.2\%), demanding (7.7\%), commanding $(7.7 \%)$, suggesting $(3.8 \%)$, asking $(1.9 \%)$, and begging $(1,9 \%)$. In the 
resolution phase, directive speech acts were suggesting (13.6\%), ordering (11.6\%), commanding $(5.8 \%)$, demanding $(3.8 \%)$, asking $(1.9 \%)$, and inviting $(1.9 \%)$. In the orientation and complication phase, ordering speech is very dominant while in the resolution phase, suggesting is dominant. This is due to the high power relations and the distance between the two main characters in the orientation and complication phases, while in the resolution phase, the interpersonal relations between the two figures are getting closer. This is evidenced by the absence of a power relation between the two figures and the close relationship of friendship at the end of the film. The aspect of discourse critique analysis of Green Book films is an interesting thing to do for further research, as well as the translation aspects of subtitling techniques and strategies because the elements of racism in this film are still very dominant.

\section{References}

[1] Searle, J. R. (1965). What is a speech act. Perspectives in the philosophy of language: a concise anthology, 2000, 253-268.

[2] Searle, John R. 1969. A Theory of Speech Acts. Cambridge: Cambridge University Press.

[3] Yule, George. 1996. Pragmatik (diterjemahkan oleh Indah Fajar Wahyuni). Yogyakarta: Pustaka Pelajar.

[4] Lailiyah, S. (2015). Directive Speech Act of the Main Characters in Divergent Movie. Journal. Situbondo. Universitas Abdurachman Saleh.

[5] https://id.bookmyshow.com/blog-hiburan/sinopsis-film-green-book-drama-rasismedibalut-sentuhan-komedi/

[6] Oktoberia, L., \& Hamzah, R. A. S. (2012). Directive Speech Acts Used In Harry PotterThe Deathly Hallow And Bride Wars Movie Script. E-Journal English Language and Literature, 1(1).

[7] Kuncara, S. D., Nababan, M. R., \& Samiati, S. (2013). Analisis terjemahan tindak tutur direktif pada novel The Godfather dan terjemahannya dalam bahasa indonesia.TransLing journal: translation and linguistics, 1(1), 1-20.

[8] Fadhilah, R., Patriantoro, P., \& Sanulita, H. (2017). Tindak Tutur Ilokusi dalam Novel Annoying Boy Karya Inesia Pratiwi.Jurnal Pendidikan dan Pembelajaran, 7(3).

[9] Saputri, K. E., Bagiya, B., \& Purwanto, J. (2018). Analisis Tindak Tutur Direktif Dalam Novel Misteri Patung Garam Karya Ruwi Meita dan Pembelajarannya dI SMA. Surya Bahtera, 6(50).

[10] https://pahe.in/green-book-2018/

[11] https://subscene.com/subtitles/green-book/indonesian/1940718

[12] https://www.thefreedictionary.com/ordering

[13] Westby, C., \& Culatta, B. (2016). Telling tales: Personal event narratives and life stories. Language, Speech, and Hearing Services in Schools, 47(4), 260-282.

[14] Harper, L. J. (2016). Using picture books to promote social-emotional literacy. Young Children, 71(3), 80-86.

[15] Walker, C. M., \& Lombrozo, T. (2017). Explaining the moral of the story. Cognition, 167, 266-281.

[16] Gunawan, F. (2017). Representasi kesantunan Brown dan Levinson dalam wacana akademik. Kandai, 10(1), 16-27.

[17] Gunawan, F. (2013). Politeness Strategy on Request Speech Act in Bugis Kendari Language. In Proceedings The 1st International Seminar on Linguistics (ISOL-I), Postgraduate Programe on Linguistics Andalas University and Linguistics Society of 
Indonesia Universitas Andalas.

[18] Santosa, R. (2017). Metode penelitian kualitatif kebahasaan.Surakarta: UNS.

[19] Austin, John L. 1962. How to Do Things with Words. Cambridge, Mass : Harvad University Press.

[20] Alan, Keith. 1986. Linguistic Meaning. London: Routledge \& Kegan Paul plc.

[21] Barry, P. (2017). Beginning theory: An introduction to literary and cultural theory. Oxford University Press.

[22] Pishghadam, R., \& Sharafadini, M. (2011). Delving into speech act of suggestion: A case of Iranian EFL learners.International Journal of Business and Social Science, 2(16).

[23] Lee, H. E. (2014). The effectiveness of apologies and thanks in favor asking messages: A cross-cultural comparison between Korea and the United States. International Journal of Intercultural Relations, 43, 335-348. 